\title{
HUMAN REALITY AND PERFECTION IN THE PHILOSOPHICAL VIEW OF SUTAN TAKDIR ALISJAHBANA
}

\author{
Hartono Margono \\ Fakultas Ushuluddin IAIN Sulthan Thaha Saifuddin \\ Jl. Arif Rahman Hakim, Telanaipura, Jambi, 36124 \\ e-mail: margono.hartono@yahoo.com
}

\begin{abstract}
Abstrak: Realitas dan Kesempurnaan Manusia dalam Perspektif Filosofis Sutan Takdir Alisjahbana. Tulisan ini difokuskan pada pemikiran Sutan Takdir Alisjahbana tentang filsafat manusia dan relevansinya dengan pemikiran Islam kontemporer. Teori nilai dasar pemikiran filsafat Eduard Sprenger meliputi agama, estetika, politik, sosial, ekonomi dan teori nilai menjadi landasan analisis terhadap studi ini. Penulis menemukan bahwa menurut filsafat Sutan Takdir Alisjahbana, dalam diri manusia terdapat unsur-unsur pokok yang menjadi sumber perilaku badani dan kualitas mental. Pemikiran filsafat Alisjahbana yang demikian tidak bisa dilepaskan dari penilaian budi dan tumbuhnya sikap tanggung jawab yang merupakan tujuan dari filsafat manusia. Selanjutnya, Alisjahbana juga merumuskan bahwa solusi terbaik dalam penyelesaian krisis kemanusiaan dewasa ini adalah dengan mengintegrasikan keseluruhan nilai dasar yang ditopang oleh nilai ketuhanan sejalan dengan rasionalitas ilmu pengetahuan modern.
\end{abstract}

\begin{abstract}
This article focuses on Sutan Takdir Alisjahbana's thoughts on the philosophy of man and its relevance to contemporary Islamic thought. This study used Eduard Sprenger's theory of six basic values of philosophy, all of which become the grounds in analysing Alisjahbana's philosophy of man and its relevance to the current Islamic thought. The author maintains that according to Alisjahbana, human behaviours, both mentally and physically, are built upon the main essence existing in human nature. He is not able to free of it unless with the effort of doing goodness. Alisjahbana's thought is much related to his assessment on human philosophy that emerges from the value system embedded in human nature reflected in the growth of responsibility is used as parameter on his philosophical thought. For Alisjahbana, the best solutions on the current problem of humanities is to balance the values supported by the idea of the divinity value in line with the rationality of today's modern science.
\end{abstract}

Keywords: Islamic philosophy, Sutan Takdir Alisjahbana, philosophy of man 


\section{Introduction}

The philosophy of man was the theme of the philosophy that would specifically reflects the nature or essence of the man. Human philosophy is often also referred to as skepticism anthropology. The philosophy of human beings have equal status with other branches of philosophy, such as ethics, epistemology, political philosophy, and cosmology. However, human philosophy also has a privileged position, because all matter that philosophy begins and ends about questions concerning the essence of the human beingas the main theme of the reflection of human philosophy. ${ }^{1}$

Similar to psychology, sociology and philosophy, human anthropology also want to understand the man and the phenomena. It can be said that the material object of the third discipline above is the same, the man who expresses himself in the world. However, the approachs used are in different methods. In general psychology, sociology, and anthropology using methods that focus on empirical facts which can be measured. These facts are then analyzed by using experimental methods. On the other hand, the philosophy of human beings does not limit itself to mere empirical facts. The study of the philosophy of man is everything about the man, so far can rationally thought out. Metaphisic, spiritual and universal dimension of the human being, that cannot be approached empirically, thus becoming the most important studies of the philosophy of man. ${ }^{2}$

Other sciences about human beings are limited in what appeared to be empirical. Human aspects which meaningful, but do not appear empirically will not have a place in the analysis of empirical studies. As a result many questions related to the essence of the human being cannot be answered by empirical human sciences. The question then what is the essence of the human being? What is the purpose of human life? And to where his life should lead? The main characteristic of the philosophy of man is his approach that is at once profound and pervasive in human understanding. As for the benefits of studying philosophy of man, is hoped to offer a form of an in-depth knowledge about all aspects of human being.

Theoretically, philosophy of man can help a person to review critically the hidden assumptions in the human theories about the performance of the knowledge. At the practical level, philosophy of man is able to help someone in making practical decisions in everyday life with the knowledge that about him. Philosophy of man can also help give meaning to what had been in the natural man in determining the purpose of life and develop culture.

S. Takdir Alisjahbana in analyzing the factors and elements of the rise of this culture is the thought of human intelligence and investigate everything based on the fact of nature.

${ }^{1}$ Zaenal Abidin, Filsafat Manusia Memahami Manusia Melalui Filsafat (Bandung: Remaja Rosdakarya, Februari, 2009), p. 3

${ }^{2}$ S. Takdir Alisjahbana, Antropologi Baru Nilai2 sebagai Tenaga Integrasi dalam Pribadi, Masyarakat dan Kebudayaan (Jakarta: Dian Rakyat, 1986), p. 8. 
Thus it is extremely relevant to the word of God in the Qur'an, how the position sense in the teaching of the Islamic religion. Seen from this perspective it is clear that Islam is a religion that renders humans as beings endowed with reason and by God, he is advisable to use his mind to think. In Q.S al-Sajdah/32: 7- 8, God said;

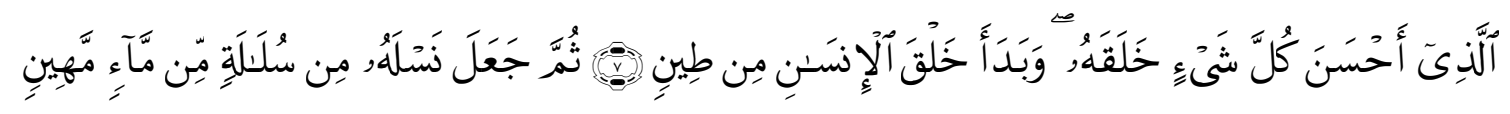

'He who made everything that he created most good and who began the creation of man from the soil. Then he made his progeny from a quintessence of the nature of fluid which is despised'. ${ }^{3}$

From the above revealed verse, that God has made man from the soil and then he made his progeny from a quintessence of water which is contemptible. To him was given a God sense to hear, see and feel, as well as the ability to understand, think and cultured. In the view of Linguistics, psychology, logic and science in modern times, it is thought that the way human beings and especially ways of thinking that produced science and culture, is a way of thinking that uses language. Ultimately, the philosophy of man can make a person realizes that man is God's most perfect creatures of the Earth.

\section{Concepts and Theories of Man}

Concepts or theories about man or human beings in the thought's system and a philoshopical framework are very important, because they are part of the philosophy of life. Human concepts are important not only because of just a knowledge about human, but the more important is that it is a requirement of critical justification and basic for human knowledge. The concept referred to is the nature of the universe (universal nature) about something. ${ }^{4}$

There are some views in the history of Islamic thought about man, as found in Philosophy and Sufism. In Islamic Philosophy and Sufism's view, the absolute truth which include virtue, perfectness, existence, the beginning of creation and the end of life. In this series of talks growing in human nature, human relationships among them, the human relationship with God and everything that was there.

In General, Islamic philosophy and Sufism's view on man is composed of two substances, i.e. substances which are material or body, and substances which are immaterial or soul, and that the essence of man is a immaterialnya substancethat served as courtiers and

${ }^{3}$ Abdullah Yusuf Ali, the Holy Quran: English Translation and Selected Commentaries (Kuala Lumpur: Saba Islamic Media, 1998), p. 501.

${ }^{4}$ S. Takdir Alisjahbana, Antropologi Baru, p. 24-25. 
other Khalifa (vicegerent) in the Earth. Humans in fact is his soul. The soul which differenciates human beings with God. With the soul, a man can feel, think, and do more. Strictly speaking, the soul is to be the very essence of the essential of human beings because of its spiritual lata'if, rabbani, and immortal after death. The safety and happiness of man in the world and the hereafter depends a lot on the State of his soul. For the soul is the subject of religion, the basis for those who walk toward God and rely on human iniquity or obedience to God. The soul that can obey, rebellious or disobedient to God Almighty.

Highness and perfection of human being are gained by enabling substances through his immaterial. The philosophy of Islam uses the word al-nafs (soul) to immaterial substances. Al-nafs has powers, and most importantly for the philosophers' thought that power is contained in it. Human perfection is obtained by way of sharpening its thinking. The muslim philosophers (al-Kindî 801-873 M, al-Farâbî 670-950 M, Ibn Sînâ 980-1037 CE) in their epistemology found that sharpening is needed so that the thinking power of human abilities at the highest level can be directly related to al-Aqlal-Fa'al or active intellect. that is a source of a wide range of knowledge.

The word al-Ruh and al-Qalb, in Sufism is used to designate the human immaterial substance. Through this, the immaterial substance through Sufis strive to achieve the highest level of perfection that they acquire knowledge about the nature of the highest through al-dzawq, the most important power in it, so it can be United with him. While alAql (intellect), in Sufism is not a paramount power due to the efforts of self improvement therein is not an intellectual process, but rather through the sharpening power-the power of intuition and emotion.

In addition to differences in views about power, there are other important differences between philosophy and Sufism. Powers that possessed by a human have effectiveness on him. In the view of the philosophers, human beings have free will and capabilities in manifestinghis actions.

In Sufism, all motion and human performance is due to the will of God and the power of human is created in his every deed. Humanowned resources are considered to be accidently do not have immortality, in a sense of each manifestation of motion or action.

Philosophy in the Islamic world have got a challenge from among the Fuqaha' (Islamic legal experts) and the mutakallimun (theologians of Islam), especially from the Ahl alSunna wa al-Jama'ah's school of thought.

The thoughts of the philosopher considered by many not in accordance with the teachings of the Qur'an, as well as view the Sufis also got a challenge from some Muslims, mostly followers of the salaf. Their views resulted in schools-schools that are contrary to understand that you found in the tradition of the salaf. Influence of the fuqaha' and mutakallimun was so strong in the Islamic world which led to their view negatively to the development of philosophy, consequentlyman are afraid to philosophize. 


\section{The Concept of Man in the Qur'an}

Discourse on the origin of man, which is more interesting to be examined in two concepts (the concept of evolution and the concept of Adam was the first man) always gives rise to the inexhaustible debate to be discussed.

On the one hand the concept of evolution offered an idea that man is the perfect manifestation of the evolution of the beings on this earth. While the second, man was a descendant of Adam and Eve. ${ }^{5}$

In this work the author doesn't discuss intensively right or wrong about both concepts, the author will emphasize the concept of man in the Qur'an and a little explanation for the concept of space for man through the theory of evolution, just as the analysis of comparison only.

If seen roughly, it is obviously that these two concepts are mutually contradict even tend to care about each other. When Darwin said that human beings were due to the evolution of other living beings. The Qur'an clearly states that man is descended from Adam and Eve expelled from paradise.

The above opinion becoming an interesting debate up to these days. Some said that Darwin is right, reasonable, while some other answered it by saying that the Qur'an was the only one which right, because this is the commandment of the Lord, the Lord Almighty and the Almighty, so that anything can be done, no exception He created Adam from clay and Hawa from Adam's left rib.

While the theory of evolution failed miserably when faced with the fact that when this ancient beings (such as the dragon comodo, crocodile, tortoise) still roam the Earth, isn't if the tracing on the theory of evolution creatures beings above should have been extinct. Who defended theory of evolution behind the inquiry. If the first man was Adam, why archeology is still found beings similar to humans lived roughly long before the existence of Adam? Discourse like this tireless muckrakers do. In case both are equally unable to conclude with certainty as to when the first humans were there.

That the existence of a human being according to the Qur'an is because the first human pair of Adam and Eve. At that, the two man profiled at originally live in heaven. But due to the violation of the commandment of God then they descended to Earth. Once delegated to the Earth, from a pair of human beings then increased in numbers, as His Deputy in the new world.

In this connection, according to S. Takdir Alisjahbana, a task which is very heavy to be guardians of the Earth. Due to the weight of a task that will run by man so God gives knowledge about everything to man. One more value on human beings, namely to be

${ }^{5}$ Kamal Faqih, Tafsir Nurul Qur'an: Sebuah Tafsir Menuju Cahaya Tuhan (Jakarta: al-Huda, 2003), p. 27. 
whelmed with knowledge. It is important that in Surah 2, verse 30 says; that with all the benefits of by man, God then set him to be His Caliph on the Earth. One policy of God was opposed by the devil and questioned by the Angels, as the word of God in Q.S al-Baqarah/ 2: 33 .

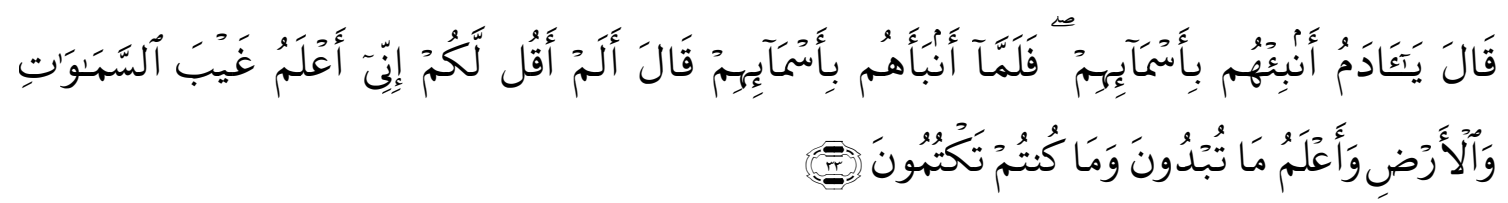

'O Adam, announce their names in this matter." And when he told them their names told them, Allah said: "Did I not tell you that I know the secrets of heavens and earth, and I know what ye reveal and what ye conceal?'6

After Adam mentioned the names, the angels finally know that man in fact able to keep world. It is understandable that man is most perfect living creatures that God created. With all knowledge that God has given, man get highest position compared to other creatures.

As described by God in His word in Q.S al-Baqarah/2:34.

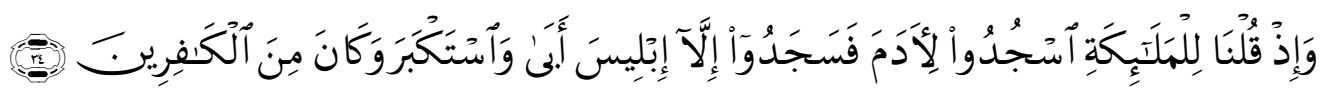

And (remember) when We said to the angels: "Bow down to Adam," they bowed down: not so Iblis: he refused and was haughty: he was of those who reject faith."

This shows that man have the features that special among other creatures of God, even with the angels. This is applied If legitimacy qualities on the model man of this time, or man in general in addition of the prophets and the special ones (al-ma'sum). The prophets and the special ones should be in exceptions because it is clear in their qualities or perfection and good will always be with them.

In the verses above explained that before the incident of Adam, God hasplanned man to bear the responsibility on the earth as His vicegerent. In order to bear that responsibility man is equipped beside physical and a soul divine (reason and spirit), he also given:

a. The potential to know the name and the function objects nature. Through this potential can be known that man is capable and cultured to arrange these concepts, created, develop put forward ideas and carry it out. This ability to prove to the angels, who had been feel it is normal to be made in the earth; finally they were willing to prostrate to Adam.

${ }^{6}$ Ali, the Holy Quran, p. 27.

${ }^{7}$ Ibid. 
b. Experience of Adam and Eve while living in the Garden and its bliss, as self-sufficient,as well as demonic plea that can lead to a prolonged both of them.

This experience was the direction that must be taken, a sufficient in clothing, food and a sense of safety and security and will be fulfilled for his blessed life in this world, and in the hereafter. In Q.S al-Baqarah/2: 201.

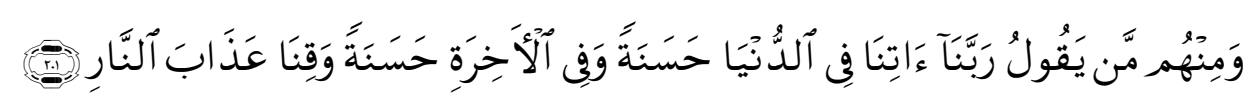

And among of them whoask: "Our Lord, give us goodness in this world and goodness in the hereafter, and defend us from the torment of the fire."

While temptations of Satan, with the result that is very serious, was an experience that is very valuable in the face appeal by Satan in the world, which at the same time warned if man adhere to his appeal, there will be trapped. In the Qur'an is explained that man have a tendency to transgress the commands of God, In fact He promised him the highest position which is much higher than other creatures. Allah said in Q.S. al, A'râf/7: 76.

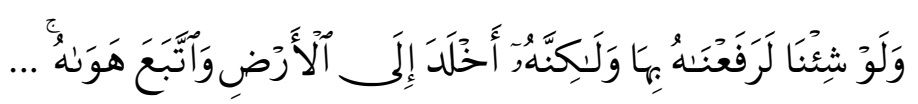

'If We had so willed, We raise (degrees with Our Signs) Signs, but he inclined to the earth, and followed his own vain desires.' 9

It can be seen from the above verse that since the beginning human beings desire to be His servants, but because of the very nature, they ignore it. This shows that man has the good potencies, but as thy are not used so man trapped in insult, sometimes even their level fell to the level under animals.

From the explanation above, in order to realize the potencies, human beings must obey the commands of Allah to be carried out and to turn away from all His banand of course human beings are able to carry out this.

In the end, their life and death will go to Allah the Almighty. All the human beings have are to remain to him, so it so failed when man forget all of this.

\section{Perfect Man}

In general, there are two key words to understand the essence of human being to the huge potential belonged to him. The key word is al Insan and al Basyar. Al-Insan is

${ }^{8}$ Ibid., p. 53.

9Ibid., p. 207. 
used to show man from the aspect thought and consciousness, meanwhile, the word alBasyaris used to point man in different dimensions naturally (physically), which is peculiar to human generally like to eat, drink and die. ${ }^{10}$ The word Insan which in Arabic came from the al-uns, anisa, nasiya and anasa, Insan, then it can be said that Insanrefer to a sense that it hasrelation with the attitude born from the awareness and reasoning. The word Insan in the Qur'an is used to show man with the body and soul, as totality. The difference between a person with others are physically, mentally and intelligence. ${ }^{11}$

The word Insan if seen from its original word nasiya which means forget, refered to a connection with self-consciousness. For this reason, if man forgetful to anything just because he had lost consciousness toward it. Then in religious life, if someone is forgetful onan obligation that he should do, he would not be guilty because of being forget, because he lost consciousness ofthe obligation, it is different from someone who intentionally disobeying the obligations. Meanwhile, the word insanto mean man derived from the root word al-uns or anisa which meansunwild and harmonious, because man could in principle adapting to the reality of life and their surroundings.

Man ability to adapt is quite high, in order to adapt for changes taking place in his life, both social change and natural conditions. Man appreciate the rules of ethics, manners, and as a cultured creature, he is not behaving wild socially as well as naturally. The solidarity values that permeates the conduct of an individual will manifest in all sort of feelings such as friendship, love, sympathy, cooperation, loyalty, justice and so on as the basis of all sorts of social relationships forms and groups, such as family, friendship, party, nation and so on. ${ }^{12}$

Meanwhile, in the view of Langgulung, the concept of man as a whole is reflected in the term al-Insan, not al-Basyar. According to Langgulung if examined the verses that stated al- basyar in the Qur'an it could be concluded that the word was only shows the form material. In this sense, al-Basyar as a general noun appeared 35 times in the Qur'an, in some places, including 25 apostles (the Prophets) as a man (basyar), by asserting the commonality, in this regard as a man and the attributes of his materiality among them (the prophets) with ordinary people. ${ }^{13}$

Based on above explanation, it can be understood that the word basyar according to Langgulung was referred to describe man as "things" (material). As material, all human beings have similarity, completed with parts of bodyand share the same natural tendencies. They need to eat, drink, rest, sleep, walk and so on. Man as material, do not show the difference between one another, because in general, all man possess it.

${ }^{10}$ AbudinNata, FilsafatPendidikan Islam (Jakarta: Logos Wacana Ilmu, 2001), p. 31.

${ }^{11}$ M. Quraish Shihab, Wawasan al-Qur'an: Tafsir Maudhu'i Atas Pelbagai Persoalan Umat (Bandung: Mizan, 2000), p. 280.

${ }^{12}$ S. TakdirAlisjahbana, AntropologiBaru, p. 103.

${ }^{13}$ Hasan Langgulung, Dasar-DasarPendidikan Islam (t.t.p.: t.p., t.t.), p. 286. 
The understanding of the meaning of the word al-basyar above according to Langgulung, seems based on etymological meaning. In language perspective, IbnZakariya explained that all these letters consisting of letters ba, syin, and $r a$, reflect a very apparent and usually beautiful. ${ }^{14}$ In line with that, al-Asfahaniy explained that al basyar is used to mean skin as it can be seen clearly. ${ }^{15}$ while according to the QuraishShihab, the man called al-basyar is because their skin is different from skin of animals which was covered with feathers, and Some quotes about the meaning al-basyar above clearly shows the emphasis on the meaning of the words is physical side that is evident, and from the side there are similarities between all human beings. ${ }^{16}$ The difference quality is clear when man understand the very meaning of the word al-Insan.

From the exposition above, it can be understood that the concept of perfect man in the Qur'an can be formulated as follows:

First, perfect man as creature was a honor from God, this means that Islam is not putting man in dishonor, humble or not valuable but he is honored. In Q.S. al-Isrâ'/17: 70, Allah Almighty said:

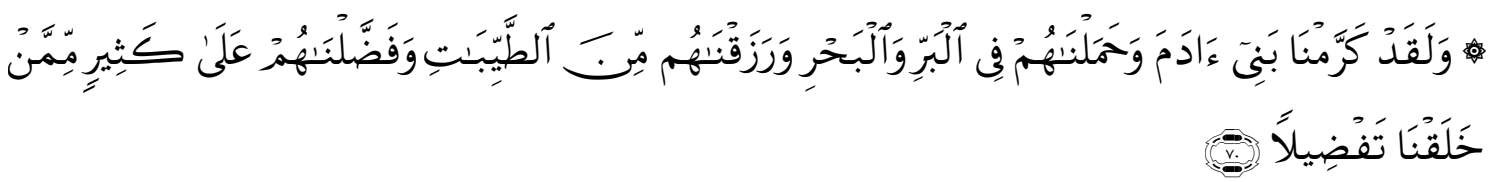

'And We have honored the sons of Adam; we carry them on the land and sea, We gave them provision of good and pure with the advantage that they are Perfect for a great part of our creation most created. ${ }^{17}$

Second, perfect man as the chosen one, is a grace of God given to human beings to be able to distinguish goodness andbadness, obedience and disobedience. Into man's heart, Allah put its readiness and desire to do good or evil. Clearly Allah says that in his life, perfect man must try to keep themselves, develop, and leave themselves in order that man was taken up in the virtues of. As He said in Q.S. al-Shams/91: 10.

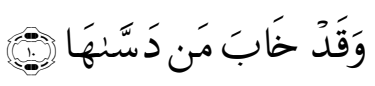

'And dissappointment be on those corrupts it. ${ }^{18}$

${ }^{14} \mathrm{Abu}$ al Hasan Ahmad ibn Faris ibn Zakariya, Mu'jam al-Muqayis fi al-Lughah (Beirut: Dar al-Fikr, 1994), p. 135.

${ }^{15}$ Al-Raghib al-Asfahaniy, Mu'jam Mufradat Alfadzh al-Qur'an (Beirut: Dar al-Fikr), p. 44.

${ }^{16}$ Shihab, Wawasan al-Qur'an, p. 279.

${ }^{17}$ Ali, The Holy Quran, p. 343.

${ }^{18} \mathrm{Ibid}$, p. 771. 
Human beings have a certain culture to be educated, He has been completed man with the ability to learn, as mentioned in Q.S. al-Alaq/96: 3-5.

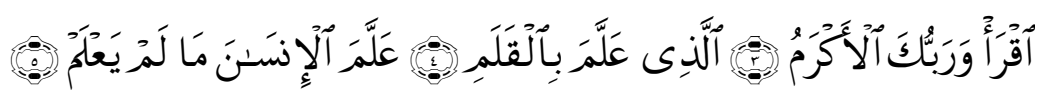

'Please read, but Your Lord is Most gracious, Who teach (men) with the mediatery of Pen, He taught man that which he knew not'19

He has created man to learn, such as the vision, hearing and their hearts. With a complete learning facility, God is always asked man in His word afalâ ta'qilûn, afalâ tatafakkarûn, and still a lot more questions from God to man which shows that human beings would be willing to learn. In the Qur'an was mentioned that human beings as the vicegerent of God, and dwell on the (earth is in itself invested qualities of the: admitted that there is a God, free, reliable, have a sense of responsibility in himself and the universe, blessed with superiority over the universe, the sky and the earth. Man armed with a tendency soul to the good or evil. Progress they started out of the weakness and inability, who then moves forward toward his power and perfection.

The Qur'an also mentioned that the properties of the weakness of the man, man are condemned, man is revealed extraordinary shameful and ignorant. Man who were not able to bear mandate given to him by God, they will be brought low rank by Allah almighty as His word in the Q.S./95 : 5-6 which reads:

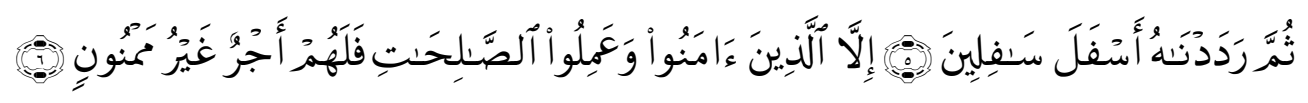

'Then We restored him to a low-low fire, Except those who believe and do righteous deeds: for they shall have a reward unfailing'20

In addition, the Qur'an also remind man who do not use his potential heart, his potential eyes, ears, to see and observe God's power signs, he is among the heedless. This assertion is stressed by God in His word at surah al-A'raf verse 179 which means: "We have made for hell is produced (most of the jinn and mankind, they have hearts wherewith they understand the Signs of Allah) and they have eyes with which they do not see signs of Allah, and ears wherewith they hear the Signs of Allah). they are like cattle, nay more misguided: for they are heedless". ${ }^{21}$

For the perfect man created by God as a living creature that most sophisticated, to be able to use all the potential he possess well, namely to actualize his potential faith in

${ }^{19}$ Ibid, p. 778.

${ }^{20}$ Ali, The Holy Quran, p.777

${ }^{21} \mathrm{Ibid}, \mathrm{p} .199$ 
God, to master the knowledge and to do good deeds, so man will be the most noble and qualified as a perfect man in accordance with his nature.

\section{Human Reality and Perfection in Alisjahbana's Philoshopical View}

Humans are creatures of God which consists of body and spirit as one unified whole. He is the most perfect creature when compared with other creatures. Is a physical material that can be seen, touched, felt, his form concrete but not immortal. If the man dies, his physic decay and disappeared. There is a spiritual being in a physical body or the body that can not be seen, can not be touched and abstract. If a human dies, the soul or spirit will be separated from the body and the the origin, The Lord. And the soul is not destroyed. The soul is the spirit that is in physical or human body as a mover and the source of life.

According to S. TakdirAlisjahbana, human Perfection lies in his moral, because man equipped by their creator with moral which only found in human soul. With logic and ration, human beings are able to create science and technology. The good and evil, which requires human beings to consider, assess and create truth, beauty, good or vice versa. With the feelings, human beings are able to create art and culture. ${ }^{22}$

In general, actions of man will produce a culture, situating actions of man in the sense that the natural actions of man who are standing by a itself and apart from the events because of human nature, not set aside by nature but by man. According to $S$. Takdir Alisjahbana, in itself however wonderful actions of man if it is compared with the phenomena in the universe, could not be released from the nature's phenomena, and even as one of the natural phenomena manifestation. In a relationship that is an area that culture is partly the manifestation of nature. ${ }^{23}$

Talking about perfect man according to S. Takdir Alisjahbanais very principle in terms of ethics, how man who desired to be realized or aspired .

In S. Takdir Alisjahbana's thought, in connection with the perfect man, begin with his tend to realize in modern man for the Indonesian man who are constantly buzzed since polemics cultures around the end of 1935. S. Takdir Alisjahbana tried to change man in Indonesia for a long time and records to modern society mastered science, technology and economy such as in Europe, which has been characterized by human spirit is perfect, the man power is a dynamic always changed from trouble. If you want to move forward one must look forward not to the rear. It is not a powerful but indigenous man from every human being.

The perfect man, the original individuals who in the long regarded as setbacks, and

${ }^{22}$ Alisjahbana, Antropologi Baru, p. 87-88.

${ }^{23}$ Alisjahbana, Kelakuan Manusia di Tengah-Tengah Alam Semesta (Jakarta: Dian Rakyat, 1984), p. 12. 
in modern society is a good. The original and advancement is at stake in the eyes of the man, the term modern old he could not have values, even in assuming that a taunt, parents have not been used anymore meaning, which has been deprecated, has become stale and has passed his time. But young man reflect modern, new, indigenous mans, fresh and their cry has reached in the future. So in modern society there are in perfect man mandynamic, fast to move toward progress. S. TakdirAlisjahbana's role not far as figures of renaissance ${ }^{24}$ in Europe, pushing the resurrection new apart from dark ages in the centuries of middle ages ago. It was for his man, to get rid of the past that is catching up and backwardness and jump to the middle arena of modern day on a par with the other nations. ${ }^{25}$

S. TakdirAlisjahbana described that the perfect man is the man who dares, optimistic and responsible as the manifestation of freedom and authority of God in him. Fear is an enemy of perfect man. The fear is often applied or purified to religion as fear of death, and fear of responsibilty for his own actions.

Perfect man thenaccording to S. TakdirAlisjahbana is a man who is free, aware and responsible for freedom for their actions. Because he is as a caliph of God who created the universe. Allah SWT has determined that human beings are created as perfect compared to another.

Meanwhile, if traced further actions of man in relationship with natural phenomena, S.Takdir Alisjahbana explained that the foundations of the similarities between the two, and for the next evolved gradually developing in the levels as revealed by destiny, in the first level, is in organic level, about the process of chemistry and physics alone. In which actions that man in essence could not be separated from the power and the laws of the chemical processes and physics, and even have been based on him. In the science, it is often ignored, but all digestion, respiration, and all movement of man revolves around questions of the chemistry and physics based on mathematical calculations. ${ }^{26}$

On the second level, the level as living creatures or organic. It is not only centered around the chemical processes or physics, but has also around biological level. Plants, animals and human beings have the same, namely vegetative life. This level provides an in-depth functions of the respiratory system, digestion, blood drive, breeding. Most of the vegetative life is chemical and physical processes, and it is not realized being occured to all by itself. ${ }^{27}$ The third level in which man and animals share the same, was not accompanied

${ }^{24}$ The flow in the middle ages (14th and 15th) who studied and gave birth to cultural and civilization for a long time from the nations Greece and Rome. Appearance because of the experts in past was driven by a sense an awards that high and awe lauar of understanding of the ancients intellect at that time, so there arose new arts and civilizations.

${ }^{25}$ Horison literary Magazine (No. 2. Chief Commodity XXII. Febrary 1988), p. p. 25.

${ }^{26}$ S. Takdir Alisjahbana, Kelakuan Manusia di Tengah-Tengah Alam Semesta, p. 25.

${ }^{27}$ Ibid., p. 26. 
by agencies and plants inorganic, which took place from the functions of motion, feelings and potential perceive. Max Scheler, ${ }^{28}$ named the life force in Botany as called Gefuhlsdrang here we have been able to talk about life. Because this level is already at consciousness' level, which has long been a favorite in a central nerve system. Finally there were process that there are only to a human being called manner. This is the final process, which is found only in humans. According to S. Takdir Alisjahbana process of this manner is also based on organic process that occurs in the cortical brain chemical and electrical process which became the qualities that produce men and culture. ${ }^{29}$

It's according to S. Takdir Alisjahbana, the moral was the most important freedom of choice, to determine and create the values, because moral is special for mankind. With the growing moral, man have the freedom that is not owned by animals that are controlled by instinct and the limited life drive. Human intellect who was the most important part and this is what distinguishes between human beings and the other beings. Man can prepare nature as an object, investigate and know the nature objectively. With the intellect and moral, man can investigate natural phenomena in order to know the laws, forces, the processes of nature's work that can meet their needs either directly or indirectly. In this regard, a man is said to have the opportunity to take over the contents surrounding nature.

From the explanation above it can be formulated the fundamental difference between humans and animals. The concept of moral which only owned by man, this makes the difference between individual of human beings and the individual of animals, human society from the animal community, man's behaviour to animal behaviour. Freedom and the possibility of moral which unlimited due to improper usage of symbols as language and so on, as well as human potential hands to fulfill creation of the manner in the concrete form. In man's life there is always is a process of influencing dynamically and dialectically between his moral and its natural environment, social environmental and cultural environmentside by side between moral and its creations, created personal growth and culture with no limit. ${ }^{30}$

As a basis for his thoughts about the theory of values and ethics, true essence of human deeds' value. S. Takdir Alisjahbana take formulation fromE. Spranger who differenciates economic, social, political, the theory, aesthetics and religion values that according to him as the result of behavior which give marks based on aims of values theory of the laws and organic power, vegetative and zoological. ${ }^{31}$

${ }^{28}$ Max Scheler (1874-1928), a German philoshoper, he emphasized that the role the values in human life based on Good manners is absolute and objective that at the same time personalistik. Dick Hartoko, Kamus Populer Filsafat (Jakarta: Raja Grafindo Persada, 2002), p. 86.

${ }^{29}$ SutanTakdirAlisjahbana, Seni dan Sastra di Tengah-Tengah Pergolakan Masyarakat dan Kebudayaan (Jakarta: Dian Rakyat, 1985), p. 73.

${ }^{30}$ S. Takdir Alisjahbana, Antropologi Baru, p. 28.

${ }^{31}$ Ibid., p. 3-4. 
S. Takdir Alisjahbana is positioning human life as a special matter. After understanding the essence of human beings' deeds and its differences with other creatures, because human beings can make judge that meant able to put objectively everything or in taking distance.It is realized or not man has a very important position: First, S. Takdir Alisjahbana putting man the highest creature as it has the ability to assess; The difference with the beasts that only relied on instinct. Second, S. Takdir Alisjahbana believe in freedom and characteristics of critical man who at the same time also bring consequences that man should be responsible for all the way, the action or the attitudes that already taken.

According to S. TakdirAlisjahbana, it needs to be understood with the highest privilege of man as a creature who has the ability to assess this is not just a virtue for humans, but it can also destroy their own man, let alone make objective in nature, man detach himself completely from nature, in the sense that man are no longer aware of that they are a part of nature. Therefore, according to S.TakdirAlisjahbana, the ability to judge or assess human freedom, human consequences are burdened with the responsibility for any conduct, act upon the attitudes taken, therefore every human behavior must have a purpose.

Furthermore S.TakdirAlisjahbana said; virtuous human duties and human labor that the world is not just surrender, devotion to God, but God created man as His representative in the world with a God-given skills in the form of mind he needs to create a culture and live in a culture in the midst of the universe. ${ }^{32}$

In line with his view, there seems to be a compliance with the word of God in Q.S. al-Qashash/28:77, He said:

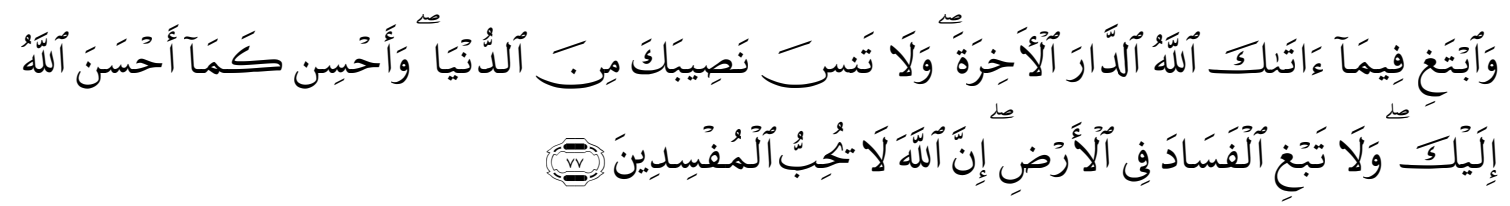

'And seek to what has been given unto you (happiness) of the hereafter, and you must never forget during all your fleeting days from (Bliss) and be good life (them) as He has to do good, you, and you must not mischief on earth. For Allah loveth not those who do mischief.'33

In the verse mentioned above that in addition to man dedicated to God, it is recommended to find a provision that was conferred by God to man in order to happiness in this world and in the hereafter, and did not do mischief, but man should be populated.

Power that was given by God, showing that man are given mandate and claimed responsibility, which in this case, it can be said that human beings were given the freedom in doing things but he should be responsible. According to S. Takdir Alisjahbana responsibility

${ }^{32}$ S. Takdir Alisjahbana, Pemikiran Islam dalam Menghadapi Globalisasi (t.t.p.: t.p, t.t.), p. 177.

${ }^{33}$ Ali, The Holy Quran, p. 474. 
of the man also includes his fate. He believes that man hold their fates themselves. According to him this is very appropriate with teachings of of Islam. That is the doctrine that man as a vicegerent on earth was very relevant, meaning that human beings must use their minds. The grant of power and intellect from God according to him that man's fate was determined by himself. Indeed God has established laws and forces in the form of the laws of chemistry, physics, veterinary, vegetative and so on, but for the choice of living in God's law is determined by the man himself and his wits. As illustrated by the verse of the Qur'an surat ar-Ra'ad (13: 11) meaning: "Allah will not change condition of a man until they change it themselves (with their own souls).

From an understanding form that verse it can be understood that man have the ability or authority to determine their own. God will not change their conditions, as long as they do not make changes in the causes of their deterioration .

The center of responsible freedom, according to S. Takdir Alisjahbana is the human's heart and conscience, which weighed responsibility and honesty in something he did, Thus the freedom that should be a staple than a responsibility of human conduct, gets its own norms in the human heart which prosecute and punish him from within his own soul. ${ }^{34}$

S. Takdir Alisjahbana's expression of how important the revelation can also be understood from his statement that was related to which the Lord has given human freedom as it is stated: "We must not forget that freedom beyond its limit means possibility to go astray," that there is a consciousness will most likely perverted that the role of revelation is very important so that man do not go lost, closer to ponder but his discovery with God. The more closely someone with $\mathrm{God}^{35}$, the more closely toward perfection and further he released from a sense of worry. More deeply sympathetic to the Lord and more meaningful in his life, and will be revealed in individual human reality or human subjective points that have dignity and prestige.

\section{The Relevance of Alisjahbana's Human Philosophy on Contemporary Islam}

According to S. Takdir Alisjahbana, tendencies or patterns of values and philosophy of a culture can be seen through the cultural character. According to S. Takdir Alisjahbana cultural character which is determined by the most favored of the six values. In this case the three main characters categoriized as follows:

First, culture that emphasizes the value of art and religion called expressive culture. Virtually culture is culture that looks back. About this clearly religious. The most noble and holy is the holy scripture manifests, when God and the gods communicate to people and sentence order which generally can not be changed man. Similarly, in the arts, all things that once created is not changing anymore, considered perfect.

\footnotetext{
${ }^{34} I b i d .$, p. 31.

${ }^{35}$ S. Takdir Alisjahbana, Antropologi Baru, p. 258 .
} 
Second, culture that emphasizes the values of science, technology and economics called progressive culture. Most important feature of science, technology and economic progress continues to be achieved.

Third, culture that emphasizes power or solidarity named cultural organizational, which might be vertical while the horizontal nature solidarity. ${ }^{36}$

According to S Takdir Alisjahbana, when the values can be realized through integration well on individuals and society, with its own crisis will not happen. Instead crisis happened in today's modern society, according to him is the result of unilateral dominance of the values available in the individual and society, ${ }^{37}$ associated with the values as the religion, economics, science, art, solidarity and the power. Religious values are placed at the highest level in Islam as a religion, Put the economy after the religion, because the economy is the principal and policy in human culture. The economy has prompted people to seek employment as much as possible from the surrounding so that it can grow with good life, and culture in its widest sense to realize and surrender to the Lord in relation to its work in the world. ${ }^{38}$

The value of knowledge has a high position placed after the economy because of human knowledge could meet its needs. Next value is placed upon the art in meeting their needs because people do not just need knowledge of God's law rules and product technology alone, but also want the result of an act that could give a beauty, neatness and cleanliness for herself.

In addition, Alisjahbana explained that the best configuration side of human philosophy is a philosophy that leads to holiness in the afterlife, an eternal life is transient in nature only a temporary life, so in this case Islamic thought and culture as the embodiment of holiness. In his philosophy, Alisjahbana sees the religion has the possibility to be the largest that can cover the entire existing values, even with religion used as the philosophy of all the values of a complicated case. Based on the fact that the whole problematic of religion includes people from the religious orders, Islam is a religion that has a greater chance to be an alternative philosophy today, because the configuration's value is the best configuration of the existing configuration. Islam presented a high human dignity and responsibility as a caliph,. which no doubt that Islam is a religion which is at first stressed the importance of knowledge.

In the face of crisis today, even though S Takdir Alisjahbana Islam offers an alternative, but that is seen as the core of his thinking though is the need for balance or progressive cultural unity and expressive crisis today because each of these cultures has been running and growing by itself, respectively.

\footnotetext{
${ }^{36} I b i d$, p. 278.

${ }^{37}$ S. Takdir Alisjahbana, Pemikiran Islam, p.124.

${ }^{38}$ Ibid. p. 179.
} 
It can be categorized as what his philosophi's thoughts contributed for contemporary Islamic Thought as follows:

\section{Conclusion}

S.TakdirAlisjahbana's philosophical thought of reality and perfect man was referring to Islamic philosophy and as a solution to the problems of human behaviour either invividual, societal and cultural in today's era. Based on the fact that it can be affirmed that Sutantakdir Alisjahbana's thought on the philosophy of man has relevance and contribution to contemporary Islamic thought. Its relevance can be shown, among others, on the need to balance the various underlying values of thought. Alisjahbana's philosophy of man was built based on idealistic, ethical and monistic philosophical thought.

Human in his thought is a creature that has a special position because of its sense of potential and existing religious tendency in him. In his life, the value of religion is a basic value most highly because it can integrate the overall value of the base in man and can answer the purpose of man's life from which his origins, for what man was created. The most important characteristic of the human mind processes is the freedom of choice, define, and creating values. Human philosophy emerges from the values of system embedded in human nature. The growth of responsibility trait serves as the aim of human philosophy. This aspect of responsibility is used as parameter on its human philosophy.

Alisjahbana tended to refer to Western figures and theologian than to Islamic ones, so he is often called as secular. On the contrary, SutanTakdirAlisjahbana's reference on human philosophy to Islam and al-Qur'an showed a new development on Sutan Alisjahbana's idea called religious values on his human philosophy. In this respect, the Islamic nuance of SutanAlisjahbana's human philosophy is obvious in that he referred and projected Islamic philosophy on his peak of thought as a problem solving to human's behavior either as an individual, society or culture in this current era. Based on the fact, it can be clearly stated that SutanAlisjahbana's thought on human philosophy has a relevance and contribution to contemporary Islamic thought. The relevance is on the need to balance various values supported the idea under the divinity value. In this respect, the contribution of Sutan Alisjahbana's idea on contemporary Islamic thought can be seen from the emphasis on rational type of thinking mode in that it should be developed in a modern Islamic idea in order to serve as one of the alternative solutions on the current problem of humanities.

\section{References}

Abidin, Zaenal. Filsafat Manusia Memahami Manusia Melalui Filsafat. Bandung: Remaja Rosdakarya, Februari, 2009.

AbudinNata. Filsafat Pendidikan Islam. Jakarta: Logos Wacana Ilmu, 2001. 
MIQOT Vol. XXXVIII No. 1 Januari-Juni 2014

al-Asfahaniy, Al-Raghib. Mu'jam Mufradat Alfadzh al-Qur'an. Beirut: Dar al-Fikr.

Ali, Abdullah Yusuf. the Holy Quran: English Translation and Selected Commentaries. Kuala Lumpur: Saba Islamic Media, 1998.

Alisjahbana, S. Takdir. Antropologi Baru Nilai2 sebagai Tenaga Integrasi dalam Pribadi, Masyarakat dan Kebudayaan. Jakarta: Dian Rakyat, 1986.

Alisjahbana, S. Takdir. Kelakuan Manusia di Tengah-Tengah Alam Semesta. Jakarta: Dian Rakyat, 1984.

Alisjahbana, S. Takdir. Pemikiran Islam dalam Menghadapi Globalisasi. Jakarta: Dian Rakyat, 1986.

Alisjahbana, S. Takdir. Kelakuan Manusia di Tengah-Tengah Alam Semesta. Jakarta: Dian Rakyat, 1986.

Alisjahbana, SutanTakdir. Seni dan Sastra di Tengah-Tengah Pergolakan Masyarakat dan Kebudayaan. Jakarta: Dian Rakyat, 1985.

Ash'ari, Musa. Manusia Pembentuk Kebudayaan dalam al-Qur'an. Yogyakarta: Lembaga Studi Filsafat Islam, 1992.

Dick Hartoko. Kamus Populer Filsafat. Jakarta: RajaGrafindo Persada, 2002.

Faqih, Kamal. Tafsir Nurul Qur'an: Sebuah Tafsir Menuju Cahaya Tuhan. Jakarta: al-Huda, 2003.

Horison Literary Magazine. No. 2. Chief Commodity XXII. Febrary 1988.

ibn Faris, ibn Zakariya, Abu al Hasan Ahmad. Mu'jam al-Muqayis fi al-Lughah. BeirutLebanese: Dar al-Fikr, 1994

Shihab, M. Quraish. Wawasan al-Qur'an: Tafsir Maudhu'i Atas Pelbagai Persoalan Umat. Bandung: Mizan, 2000. 


\title{
PUSAT-PUSAT PERKEMBANGAN TAREKAT NAQSYABANDIYAH DI TAPANULI BAGIAN SELATAN
}

\author{
Erawadi \\ Fakultas Ilmu Tarbiyah dan Keguruan IAIN Padangsidimpuan \\ Jl. Imam Bonjol KM 4,5 Sihitang, Padangsidimpuan 22733 \\ e-mail: era08_nad@yahoo.co.id
}

\begin{abstract}
Abstrak: Tulisan ini menelusuri perkembangan tarekat Naqsyabandiyah di wilayah Tapanuli Bagian Selatan melalui beberapa pusat tarekat Naqsyabandiyah dengan menggunakan prinsip sejarah lokal. Tarekat ini di kawasan tersebut datang dari dua sumber, yaitu dari Minangkabau, Sumatera Barat, dan Babussalam, Langkat, Sumatera Utara. Pengaruh dari Minangkabau terutama melalui Syaikh Ibrahim Kumpulan, sedangkan dari Babussalam, Langkat melalui Syaikh Abdul Wahab Rokan. Namun demikian, sebagian Syaikh Naqsyabandiyah asal Tapanuli Bagian Selatan, setelah belajar pada Syaikh setempat, pergi dan belajar di Haramain. Sebagian mereka belajar langsung pada Syaikh Sulaiman Zuhdi atau Syaikh Ali Ridha di Jabal Abu Qubaisy. Di antara pusat-pusat perkembangan tarekat Naqsyabandiyah di Tapanuli Bagian Selatan adalah Hutapungkut, Aek Libung, Sayurmatinggi, Nabundong, Sipirok, Pudun, Aek Tuhul, Ujung Padang, dan Batu Gajah. Kebanyakan organisasi tarekat ini telah bertahan selama beberapa generasi, namun sebagiannya tidak bertahan karena faktor-faktor tertentu.
\end{abstract}

\begin{abstract}
The Centres of Tarekat Naqshabandiyah in South Tapanuli Region. Using the principles of local history, this article traces the developments of Thariqat Naqshabandiyah in Southern Tapanuli through its many centers of activities. This thariqat reached the region by ways of Minangkabau West Sumatra and Babussalam Langkat North Sumatra with Syaikh Ibrahim Kumpulan and Syaikh Abdul Wahab Rokan being the central figures. However, some of the region's Naqshabandiyah syaikhs, after learnign under local masters, continue their learning to Haramayn, Hijaz. Mostly, they learn under the celebrated Syaikh Sulayman Zuhdi or Syaikh Ali Ridha at Jabal Abu Qubaysh. The most important Naqshabandiyah center of the region are to be found in Hutapungkut, Kotanopan, Mandailing Natal; Aek Libung, Sayurmatinggi, Nabundong, Sipirok, Tapanuli Selatan; Pudun, Aek Tuhul, Ujung Padang, Padangsidimpuan; and Batu Gajah, Barumun, Padang Lawas. Most of these centers have survived for generations; some, however, have not survived for different reasons.
\end{abstract}

Kata Kunci: tarekat Naqsyabandiyah, pusat tarekat, Tapanuli Selatan 